\title{
Qualitative and quantitative determination of phytochemicals in Convolvulus leiocalycinus and Haloxylon griffithii
}

Munir Ahmad ${ }^{1}$, Attiq-ur-Rehman ${ }^{1}$, Samiullah $^{*}$, Rasool Bakhsh Tareen $^{2}$, Naqeebullah Khan ${ }^{1}$, Abdul Baqi ${ }^{1,3}$ and Abdul Manan ${ }^{4}$

1. Department of Chemistry, University of Balochistan, Quetta 87300-Pakistan

2. Department of Botany, University of Balochistan, Quetta 87300-Pakistan

3. Government Postgraduate Science College, Quetta 87300-Pakistan

4. Institute of Biochemistry, University of Balochistan, Quetta 87300-Pakistan

*Corresponding author's email: sami435889@yahoo.com

\section{Citation}

Munir Ahmad, Attiq-ur-Rehman, Samiullah, Rasool Bakhsh Tareen, Naqeebullah Khan, Abdul Baqi and Abdul Manan. Qualitative and quantitative determination of phytochemicals in Convolvulus leiocalycinus and Haloxylon griffithii. Pure and Applied Biology. Vol. 8, Issue 1, pp733-741.

http://dx.doi.org/10.19045/bspab.2019.80015

\begin{tabular}{|c|c|c|c|}
\hline Received: 09/11/2018 & Revised: $15 / 01 / 2019$ & Accepted: 21/01/2019 & Online First: 00/01/2019 \\
\hline
\end{tabular}

\section{Abstract}

The purpose of the present assessment was to evaluate the phytochemicals in the indigenous plants Convolvulus leiocalycinus of Convolvulaceae family and Haloxylon griffithii of Chenopodiaceae family found in the northern regions of Balochistan. For the analysis of phytochemicals, both plants showed the presence of alkaloids, flavonoids, terpenoids, tannins, saponins, carbohydrates, cardiac glycosides, reducing sugars, quinones and carboxylic acids. Whereas, both plants exhibited negative tests for terpenoids, anthraquinones, phlobatannins, fats, xanthoprotien, resins, anthocyanins, emodins and volatile oil. Furthermore, with the help of standard chemical tests and techniques, the quantitative analysis of $C$. leiocalycinus and $H$. griffithii showed different amounts and percentages of total alkaloids, flavonoids, saponins and phenolics. The total alkaloid contents determined were $0.196(\mathrm{~W} / \mathrm{w})$ with percentage yield $3.92 \%$ and $0.224(\mathrm{~W} / \mathrm{w})$ with percentage yield $4.48 \%$ in $5 \mathrm{gm}$ of each sample of $C$. leiocalycinus and $H$. griffithii respectively. The total flavonoid contents determined were $0.28(\mathrm{~W} / \mathrm{w})$ with $2.8 \%$ and $0.445(\mathrm{~W} / \mathrm{w})$ with $4.45 \%$ in $10 \mathrm{gm}$ of each sample of both the plants. The total saponin contents determined were $0.72(\mathrm{~W} / \mathrm{w})$ with $3.6 \%$ and $0.53(\mathrm{~W} / \mathrm{w})$ with $2.65 \%$ in $20 \mathrm{gm}$ of each sample of both the plants. The total phenolic contents determined were $0.808(\mathrm{~W} / \mathrm{w})$ with $16.16 \%$ and $0.268(\mathrm{~W} / \mathrm{w})$ with $5.36 \%$ in $5 \mathrm{gm}$ of each sample of both the plants. The presence of high amount of phytochemical compounds suggest that both plants i.e., C. leiocalycinus and $H$. griffithii are not only useful to human beings but can also be commercialized for higher production of natural drugs rather than using synthetic drugs with side effects.

Keywords: Convolvulus leiocalycinus; Extraction; Haloxylon griffithii; Phytochemicals;

Phytochemical screening

\section{Introduction}

Phytochemicals are plants based naturally occurring substances. More than ten thousand of these phytochemicals have been identified and many still unknown [1]. Phytochemicals include alkaloids, flavonoids, steroids, terpenoids, tannins, phenols, glycosides etc. [2]. The 
therapeutic use of phytochemicals or medicinal plants have been reported in the ancient traditions and cultures of several societies for many centuries. The reason for their wide therapeutic use are low cost and safe nature than synthetic molecules $[3,4]$. Therapeutic processes of phytochemicals involve many biological and pharmacological effects such as antitumoral, anti-microbial, pro-oxidant or anti-oxidant, anti-inflammatory, antiviral and anti-mutagenic activities [5-7]. Nowadays, positive results in clinical trials have attracted many phytochemicals into medical practices [8]. In addition to therapeutic effects, phytochemicals are also used as coloring, flavoring and aromatic agents from time immemorial [9].

As stated by World Health Organization (WHO), around $80 \%$ people in developing states depend on traditional drugs for their main health requirements and about $85 \%$ of these medicines are the plant extracts [10]. The fertile land of Pakistan has a wide variety of medicinal plants and many of these need to be explored for their chemical constituents. Such information would be helpful in determining the actual value of folkloric remedies [11].

This research study involves for the first time, collection, identification, extraction and phytochemical screening of $C$. leiocalycinus and $H$. griffithii. Furthermore, C. leiocalycinus is under shrub having woody branches covered with spines, leaves $12-17$ (-24) x (3-) 5-7mm, flowers axillary, solitary, ovary glabrous, style c. $9 \mathrm{~mm}$ long, c. 3 times the length of the cylindrical stigma. C. leiocalycinus belongs to the family Convolvulaceae. They are annual or perennial shrub found in higher mountainous regions and rugged slopes of Balochistan (Pakistan) [12].

On the other hand, H. griffithii is a genus of shrubs or small trees, belonging to the plant family Chenopodiacea, floral leaves reduced on short spikes. Flowers quite distant. Perianth segments ovate, obtuse, till $1.5 \mathrm{~mm}$ tall. stamens 5; having fruiting perianth wings of white to pinkish or yellowish in color. A very common bush in Balochistan \& Khyber Pakhtunkhwa provinces of Pakistan with few records from Chitral and Gilgit. It is also distributed in Afghanistan and Central Asia [13].

\section{Materials and methods Sampling}

Different parts of $C$. leiocalycinus and $H$. griffithii such as stems, branches, leaves, flowers and roots were collected from different locations of Hanna Lake, Urak region and Spinni road of Quetta, Balochistan on $3^{\text {rd }}$ of September 2017. The samples were identified by Rasool Bakhsh Tareen, an eminent Botanist, University of Balochistan, Quetta. The samples were dried in shadow, grounded into powder form and sieved (Mesh No 325). The powdered samples were stored in plastic zip bags before use.

\section{Extraction of plant material}

The powdered plant substance weighed $4 \mathrm{~kg}$ was soaked in 15-liter methanol $(99.8 \%)$ for a period of 7 days. The mixture was filtered by Whatman filter paper No.40 $(125 \mathrm{~mm})$ followed by re-extraction of the remaining crude with methanol $(99.8 \%) 5$ liters unless the color of the solvent changed. Methanol was removed using a rotary evaporator and the dry crude methanolic extract (CME) of $C$. leiocalycinus having weight $200 \mathrm{~g}$ and $H$. griffithii having weight $210 \mathrm{~g}$ were extracted. The CME of both plants were stored in an airtight container in a cool, dark and dry place and were used for further phytochemical screening.

\section{Phytochemical screening}

The plant extracts were further used for the analysis of various phytochemicals qualitatively and quantitatively.

\section{Qualitative phytochemical analysis}

The qualitative analysis of phytochemicals such as alkaloids, flavonoids, tannins, phenolics, saponins, terpenoids, carbohydrates, glycosides, quinones, anthraquinones, phlobatannins, fats, xanthoprotein, resins, carboxylic acids, anthocyanins, emodins and volatile oil were 
carried out using several standard analytical techniques and procedures.

\section{Test for alkaloids}

For alkaloids, $0.55-0.65 \mathrm{~g}$ of the crude methanolic extract was mixed with $8.5 \mathrm{ml}$ of $1 \%$ hydrochloric acid followed by warming and filtration. The filtrate was divided into three equal parts in separate test tubes and blended with Wagner's chemical, Mayer's chemical and Dragandroff's reagent and then noted the precipitate formation and color change [14].

\section{Test for flavonoids}

For testing the presence of flavonoids, the plant extract was first treated with petroleum ether for the removal of fats. To the remnant, $80 \%$ of $20.5 \mathrm{ml}$ ethanol was blended and strained. The remainder was utilized for the tests mentioned below.

1. The remainder was treated with $4.5 \mathrm{ml}$ of $1 \%$ potassium hydroxide and examined the color change [15].

2. The presence of flavonoids was also checked by treating the filtrate with $5.5 \mathrm{ml}$ of ammonia solution and condensed sulphuric acid and examined the color alteration [16].

\section{Test for tannins}

$0.55 \mathrm{~g}$ of plant extract was liquified in $20.5 \mathrm{ml}$ of purified water and was strained. The remainder was treated with $0.1 \%$ of ferric chloride and a brownish green color was noted for the presence of tannins [17].

\section{Test for phenolics}

Two procedures were followed to test the presence of phenolics. They were:

1. The plant CME was blended with a few drops of neutral ferric chloride solution and intense violet color change was examined.

2. For another test of phenolics, a little amount of each plant extract was first dissolved in purified water and then $(3.5 \mathrm{ml})$ of $3 \%$ lead acetate was mixed with plant extract, after which formation of bulky white precipitates was observed [18].

\section{Tests for saponins}

For saponins, $0.55 \mathrm{~g}$ of plant essence was quivered with distilled water and was warmed until it boiled. The blend was shuddered to lather emergence [19].

\section{Test for carbohydrates}

\section{Molisch's test}

The plant extract was treated with $10 \%$ alcoholic alpha naphthol followed by the addition of $2.5 \mathrm{ml}$ sulphuric acid. The presence of carbohydrates and glycosides were confirmed by the appearance of bluish violet region.

\section{Fehling's test}

To perform Fehling's test for carbohydrate's presence, the Fehling's solution was prepared and was labeled as A and B. From both the solutions, $5.5 \mathrm{ml}$ was added to the plant essence and was heated. The development of reddish brown precipitates was observed for the presence of reducing sugars.

\section{Detection of cardiac glycosides}

For cardiac glycosides, $2.5 \mathrm{ml}$ of glacial acetic acid was treated with $0.55 \mathrm{ml}$ of the plant essence, with the addition of few drops of ferric chloride (5\%). To this blend, $1 \mathrm{ml}$ of sulphuric acid was mixed and development of a brown ring showed the presence of cardiac glycosides [20].

\section{Test for quinones}

$1.5 \mathrm{ml}$ of sulphuric acid was treated with plant extract and a red color formation was noted showing the presence of quinones [21].

\section{Carboxylic acids}

For carboxylic acids, $3 \mathrm{ml}$ methanolic extract was mixed with $3 \mathrm{ml}$ of sodium bicarbonate solution. Effervescence due to carbon dioxide showed the presence of carboxylic acids [22].

\section{Quantitative phytochemical analysis}

Quantitative analysis of the plants extract was conducted to evaluate the amounts and percentages of various phytochemicals such as total alkaloids, flavonoids, phenolics and saponins by means of standard chemical tests and techniques.

\section{Test for total alkaloids}

Quantitative estimation of alkaloid was performed by using the procedure of Harborne. Exactly $200 \mathrm{~cm}^{3}$ of $10 \%$ acetic acid in ethanol was mixed with each plant 
powder sample $5 \mathrm{gm}$ in a $250 \mathrm{~cm}^{3}$ beaker and kept for 4 hours. The essence was condensed on a water bath to one-fourth of the actual magnitude and then 15 drops of condensed ammonium hydroxide were added drop by drop to the extract. The floating substance was removed, and the precipitates were cleaned through $20 \mathrm{~cm}^{3}$ of $0.1 \mathrm{M}$ ammonium hydroxide solution and then sieved. The filtrate was desiccated in an oven and weighed by electronic balance and the percentage of alkaloid was calculated [23].

\section{Test for flavonoids}

Flavonoids were determined by the procedure described by Bohm and KocipaiAbyazan. Precisely, $50 \mathrm{~cm}^{3}$ of $80 \%$ aqueous methanol was blended to $10 \mathrm{gm}$ of sample in a $250 \mathrm{~cm}^{3}$ beaker enveloped and kept for 24 hours at normal temperature. After disposal the floating substance, the remainder was extracted thrice with the identical magnitude of ethanol once more. Whatman filter paper having number 42 $(125 \mathrm{~mm})$ was utilized to sieve the entire solution of wood specimen. Each specimen remainder was later shifted into a container and desiccated above a water bath. The material in the crucible was cooled through desiccator, weighed and calculated the percentage of flavonoids [24].

\section{Test for saponins}

Saponin quantitative estimation was performed by means of the modern procedure. Accurately, $100 \mathrm{~cm}^{3}$ of $20 \%$ aqueous ethanol was mixed with 20 grams of each plant powder sample in a $250 \mathrm{~cm}^{3}$ conical flask. The mixture was heated above a hot water bath for 4 hours with constant stirring at a temperature of almost $55^{\circ} \mathrm{C}$. The remainder of the mixture was extracted once more with another $100 \mathrm{~cm}^{3}$ of $20 \%$ aqueous ethanol after filtration and heated for 4 hours at a persistent temperature of $55^{\circ} \mathrm{C}$ with continuous stirring. The collective decoction was vaporized to $40 \mathrm{~cm}^{3}$ above water bath at $90^{\circ} \mathrm{C}$. After this, $20 \mathrm{~cm}^{3}$ of diethyl ether was mixed to the distillate in a $250 \mathrm{~cm}^{3}$ separating funnel and strongly blended. Afterward, the aqueous layer was retrieved whereas the ether layer was removed. This refinement procedure was repeated two times. Then, $60 \mathrm{~cm}^{3}$ of $\mathrm{n}$ butanol was mixed and extracted two times with $10 \mathrm{~cm}^{3}$ of $5 \%$ sodium chloride. Later removing the sodium chloride layer, the residual solution was heated through water bath for half an hour. After that, the solution was shifted into a container and was desiccated by an oven to get a constant weight. The saponin extract was weighed and computed the percentage [25].

\section{Test for total phenolics}

The estimation of total phenolics was accomplished quantitatively using the procedure described by Hagerman. Through this procedure, $5 \mathrm{~g}$ of powder plant samples were treated separately with $200 \mathrm{ml}$ of n-hexane twice for 3 hours each. The filtrate was removed from the residue for the preparation of fat free sample. Then residue was heated on water bath for 20 minutes with $100 \mathrm{ml}$ diethyl ether twice and then cooled to room temperature. The solution was filtered and was transferred in a separating funnel. The filtrate was treated with $50 \mathrm{ml}$ of $10 \% \mathrm{NaOH}$ solution two times and was quivered well each time. The organic layer was isolated from the aqueous layer. It was washed two times with $50 \mathrm{ml}$ deionized water. The aqueous layer was acidulated up to $\mathrm{pH} 4$ by the addition of $10 \% \mathrm{HCl}$ solution and $100 \mathrm{ml}$ dichloromethane. Subsequently, the organic layer was collected and dried over water bath, weighed and determined the percentage of phenolics [26].

\section{Results and discussion}

The purpose of the current investigation is to assess the phytochemical composition of the methanolic extract of $C$. leiocalycinus of Convolvulaceae family and $H$. griffithii of the Chenopodiaceae family by qualitative methods and also to determine the amounts of phytochemicals by quantitative analysis using various standard procedures.

Natural products are not only a good source of phytochemicals utilized as drugs but also 
assist in the manufacture of new effective synthetic drugs. The phytochemical analysis of these indigenous plants showed very exciting results. The screening of the phytochemicals extracted from these plants showed positive tests for the presence of alkaloids, flavonoids, tannins, phenolics, saponins, carbohydrates, glycosides, quinones and carboxylic acids given in the (Table 1). However, phytochemicals such as terpenoids, anthraquinones, phlobatannins, fats, xanthoprotien, resins, emodins, volatile oil, and anthocyanins showed negative tests for both plants given in the (Table 2).

\section{Quantitative Analysis}

The quantitative estimation of the examined plants revealed that phytochemicals are present in different amounts in each plant extract. The total alkaloid contents determined were $0.196(\mathrm{~W} / \mathrm{w})$ with percentage yield $3.92 \%$ and $0.224(\mathrm{~W} / \mathrm{w})$ with percentage yield $4.48 \%$ in $5 \mathrm{gm}$ of each sample of the $C$. leiocalycinus and $H$. griffithii. The result showed that alkaloid content was greater in H. griffithii than C. leiocalycinus (Table 3 ). Similarly, the total flavonoid contents determined were $0.28(\mathrm{~W} / \mathrm{w})$ with percentage yield $2.8 \%$ and $0.445(\mathrm{~W} / \mathrm{w})$ with percentage yield $4.45 \%$ in $10 \mathrm{gm}$ of each sample of both the plants. The flavonoid content was higher in $H$. griffithii than C. leiocalycinus (Table 4).

Moreover, the total saponin contents determined were $0.72(\mathrm{~W} / \mathrm{w})$ with percentage yield $3.6 \%$ and $0.53(\mathrm{~W} / \mathrm{w})$ with percentage yield $2.65 \%$ in $20 \mathrm{gm}$ of each sample of both the plants. The results revealed that the concentration of saponins was higher in $C$. leiocalycinus as compared to H. griffithii (Table 5).

Consequently, the total phenolic contents determined were $0.808(\mathrm{~W} / \mathrm{w})$ with percentage yield $16.16 \%$ and $0.268(\mathrm{~W} / \mathrm{w})$ with percentage yield $5.36 \%$ in $5 \mathrm{gm}$ of each sample of $C$. leiocalycinus and $H$. griffithii.
The phenolic contents were higher in $C$. leiocalycinus than $H$. griffithii (Table 6). Concluding these results, it can be simply judged that the phenolic contents are higher than the contents of alkaloids, flavonoids and saponins of both the plants.

The results from the quantitative analysis showed significant variations among the contents of alkaloids, flavonoids, saponins and phenolics when compared with one other. These variations are due to number of environmental factors such as climate, altitude, rainfall etc. [27].

From the literature survey it was found that alkaloids and phenolic compounds show antidiabetic properties, anti-inflammatory, antimicrobial and antioxidant effects. Similarly, flavonoids have wide range of biological properties such as antiinflammatory, antibacterial, antiviral, antiallergic, cytotoxic and antitumor properties. It is used in the treatment of neurodegenerative diseases and has vasodilatory action.

In addition, saponins exhibit antimicrobial activity extremely to coldblooded animals, but toxicity to mammals is low. Saponins are mild detergent utilized in intracellular histochemistry staining to allow antibody access to intracellular proteins. The saponins are used in hypercholestrolaemia, hyperglycemia, antioxidant, anticancer, anti-inflammatory activity and weight loss [28].

Tannins are also involved in treatment of non-insulin dependent diabetes mellitus by enhancing the glucose uptake and inhibiting adipogenesis. The most striking feature about quinones is their pharmacological properties that make them different from other secondary metabolites. It inhibits HIV 1 reverse transcriptase and shows antitumor and immunomodulatory activities. It also has antimicrobial, anticancer, antiviral and antibacterial properties [29]. 
Table 1. It shows the summary of the positive tests of different phytochemicals in $C$. leiocalycinus and $\mathrm{H}$. griffithii

\begin{tabular}{|c|c|c|c|c|c|}
\hline \multirow[b]{2}{*}{ S. No } & \multirow[b]{2}{*}{ Phytochemicals } & \multirow[b]{2}{*}{ Tests } & \multirow[b]{2}{*}{ Observation } & \multicolumn{2}{|c|}{ Results } \\
\hline & & & & $\begin{array}{l}\text { Convolvulus } \\
\text { leiocalycinus }\end{array}$ & $\begin{array}{c}\text { Haloxylon } \\
\text { griffithii }\end{array}$ \\
\hline \multirow[t]{3}{*}{1} & Alkaloids & $\begin{array}{c}2 \mathrm{ml} \text { of plant essence }+ \\
\text { few drops of Wagner's } \\
\text { reagent }\end{array}$ & $\begin{array}{l}\text { Red precipitates are } \\
\text { formed }\end{array}$ & ( & + \\
\hline & " " " " " " & $\begin{array}{l}1 \mathrm{ml} \text { filtrate + few drops } \\
\text { of Mayer's chemical. }\end{array}$ & $\begin{array}{c}\text { white precipitates } \\
\text { appeared }\end{array}$ & + & + \\
\hline & " " " " " " & $\begin{array}{l}1 \mathrm{ml} \text { of filtrate }+2 \mathrm{ml} \text { of } \\
\text { Dragandroff's reagent }\end{array}$ & $\begin{array}{l}\text { Yellow precipitate } \\
\text { appeared }\end{array}$ & + & + \\
\hline \multirow[t]{2}{*}{2} & Phenols & $\begin{array}{l}\text { Plant essence }+ \text { few } \\
\text { drops of neutral } \mathrm{FeCl}_{3} \\
\text { solution }\end{array}$ & $\begin{array}{l}\text { Intense color } \\
\text { developed }\end{array}$ & + & + \\
\hline & " " " " " " " " & $\begin{array}{c}0.5 \mathrm{~g} \text { plant essence } \\
\text { dissolved in distilled } \\
\mathrm{H}_{2} \mathrm{O}+3 \mathrm{ml} \text { of } 10 \% \text { lead } \\
\text { acetate }\end{array}$ & $\begin{array}{c}\text { Bulky white } \\
\text { precipitates appeared }\end{array}$ & + & + \\
\hline 3 & Saponins & $\begin{array}{c}0.5 \mathrm{~g} \text { of essence was } \\
\text { dissolved in boiling } \\
\text { water in a test tube, } \\
\text { was cooled and shaken } \\
\text { vigorously }\end{array}$ & $\begin{array}{c}\text { Froth formation was } \\
\text { observed }\end{array}$ & + & + \\
\hline \multirow[t]{2}{*}{4} & Flavonoids & $\begin{array}{c}3 \mathrm{ml} \text { of fats free filtrate } \\
+4 \mathrm{ml} \text { of } 1 \% \text { potassium } \\
\text { hydroxide }\end{array}$ & $\begin{array}{l}\text { Dark yellow color } \\
\text { observed }\end{array}$ & + & + \\
\hline & " " " " " " " & $\begin{array}{c}5 \mathrm{ml} \text { of dil. ammonia } \\
\text { solution }+ \text { extract }+ \\
\mathrm{H}_{2} \mathrm{SO}_{4}\end{array}$ & $\begin{array}{l}\text { Yellow coloration } \\
\text { observed, which } \\
\text { decolorized on } \\
\text { addition of acid. }\end{array}$ & + & + \\
\hline 5 & Tannins & $\begin{array}{c}0.5 \mathrm{~g} \text { extract was boiled } \\
\text { in } 20 \mathrm{ml} \text { of distilled } \\
\text { water, filtered }+0.1 \% \\
\mathrm{FeCl}_{3}\end{array}$ & $\begin{array}{c}\text { Brownish green or a } \\
\text { blue-black } \\
\text { coloration observed }\end{array}$ & + & + \\
\hline 6 & Quinone & $\begin{array}{l}\text { Plant extract }+1 \mathrm{ml} \\
\text { conc. sulphuric acid }\end{array}$ & $\begin{array}{c}\text { Formation of red } \\
\text { color was observed }\end{array}$ & + & + \\
\hline 7 & Carbohydrates & $\begin{array}{c}\text { Molisch's test } \\
\text { Water solution of } \\
\text { extract }+10 \% \text { alcoholic } \\
\text { alpha naphthol }+2 \mathrm{ml} \\
\text { sulphuric acid }\end{array}$ & $\begin{array}{l}\text { Appearance of bluish } \\
\text { violet zone }\end{array}$ & + & + \\
\hline 8 & $\begin{array}{l}\text { Cardiac } \\
\text { glycosides }\end{array}$ & $\begin{array}{c}0.5 \mathrm{ml} \text { of plant } \\
\text { concentrate }+2 \mathrm{ml} \text { of } \\
\text { glacial acetic acid }+ \\
\text { few drops of } 5 \% \text { ferric } \\
\text { chloride }+1 \mathrm{ml} \text { of conc. } \\
\text { sulphuric acid }\end{array}$ & $\begin{array}{l}\text { Formation of brown } \\
\text { ring at the interface } \\
\text { was observed }\end{array}$ & + & + \\
\hline 9 & $\begin{array}{l}\text { Carboxylic } \\
\text { acids }\end{array}$ & 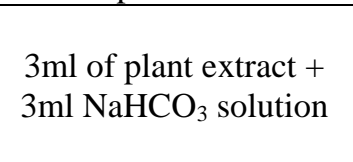 & $\begin{array}{l}\text { Effervesces due to } \\
\mathrm{CO}_{2} \text { indicate the } \\
\text { presence of } \\
\text { carboxylic acids }\end{array}$ & + & + \\
\hline
\end{tabular}


Table 2. It shows the summary of the negative tests of different phytochemicals in $C$. leiocalycinus and H. griffithii

\begin{tabular}{|c|c|c|c|c|c|}
\hline \multirow[b]{2}{*}{ S. No } & \multirow[b]{2}{*}{ Phytochemicals } & \multirow[b]{2}{*}{ Tests } & \multirow[b]{2}{*}{ Observation } & \multicolumn{2}{|c|}{ Results } \\
\hline & & & & $\begin{array}{l}\text { Convolvulus } \\
\text { leiocalycinus } \\
\end{array}$ & \begin{tabular}{|l} 
Haloxylon \\
griffithii
\end{tabular} \\
\hline 10 & Terpenoids & $\begin{array}{c}5 \mathrm{ml} \text { of extract of each }+2 \mathrm{ml} \\
\mathrm{CHCl}_{3}+3 \mathrm{ml} \text { of } \mathrm{H}_{2} \mathrm{SO}_{4}\end{array}$ & $\begin{array}{c}\text { A boundary with a } \\
\text { reddish-brown color } \\
\text { observed }\end{array}$ & 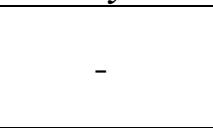 & $\begin{array}{lll} & 0.0 \\
\end{array}$ \\
\hline 11 & Anthraquinones & $\begin{array}{c}2 \mathrm{ml} \text { methanolic extract }+ \text { few } \\
\text { drops of } 2 \% \mathrm{HCl}\end{array}$ & $\begin{array}{l}\text { Red color } \\
\text { precipitates }\end{array}$ & - & - \\
\hline 12 & Phlobatannins & $\begin{array}{c}2 \mathrm{ml} \text { methanolic extract }+ \text { few } \\
\text { drops of } 10 \% \text { ammonia solution }\end{array}$ & $\begin{array}{l}\text { Pink color } \\
\text { precipitates }\end{array}$ & - & - \\
\hline 13 & Fats & $\begin{array}{c}5 \mathrm{ml} \text { of } 0.5 \mathrm{~N} \mathrm{KOH}+10 \mathrm{ml} \text { of } \\
\text { methanolic extract }+ \text { few drops } \\
\text { phenolphthalein }+ \text { heat for } 2- \\
\text { hours }\end{array}$ & $\begin{array}{l}\text { Soap formation or } \\
\text { partial } \\
\text { neutralization of } \\
\text { alkali } \\
\end{array}$ & - & - \\
\hline 14 & Xanthoprotien & $\begin{array}{c}2 \mathrm{ml} \text { methanolic extract }+0.5 \mathrm{ml} \\
\text { Conc. } \mathrm{HNO}_{3}+0.5 \mathrm{ml} \mathrm{NH} \mathrm{NH}_{3}\end{array}$ & $\begin{array}{l}\text { Reddish orange } \\
\text { precipitates }\end{array}$ & - & - \\
\hline 15 & Resins & $\begin{array}{l}2 \mathrm{ml} \text { methanolic extracts }+5-6 \\
\text { drops acetic anhydride solution } \\
+1 \mathrm{ml} \text { Conc. } \mathrm{H}_{2} \mathrm{SO}_{4}\end{array}$ & $\begin{array}{l}\text { Resins give } \\
\text { coloration ranging } \\
\text { from orange to red }\end{array}$ & - & - \\
\hline 16 & Anthocyanins & $\begin{array}{c}3 \mathrm{ml} \text { methanolic extracts }+3 \mathrm{ml} \\
2 \mathrm{NHCl}+\text { few drops } \mathrm{NH}_{3} \\
\text { solution }\end{array}$ & Pinkish red color & - & - \\
\hline 17 & Emodins & $\begin{array}{c}3 \mathrm{ml} \text { methanolic extract }+3 \mathrm{ml} \\
\mathrm{NH}_{4} \mathrm{OH} \text { solution }+3 \mathrm{ml} \text { benzene }\end{array}$ & Red color & - & - \\
\hline 18 & Volatile oil & $\begin{array}{l}\text { 4ml methanolic extract }+2 \mathrm{ml} \\
\text { dilute } \mathrm{NaOH}+2 \mathrm{ml} \text { dil. } \mathrm{HCl}\end{array}$ & $\begin{array}{c}\text { Formation of } \\
\text { white precipitates }\end{array}$ & - & - \\
\hline
\end{tabular}

Table 3. It shows the quantities and percentages of alkaloids in $C$. leiocalycinus and $H$. griffithii

\begin{tabular}{|c|c|c|c|}
\hline Plant species & $\begin{array}{c}\text { Weight of } \\
\text { sample }\end{array}$ & $\begin{array}{c}\text { Weight of } \\
\text { alkaloid }\end{array}$ & \% age of alkaloid = weight of alkaloid $\mathbf{x ~ 1 0 0}$ \\
\hline weight of sample
\end{tabular}

Table 4. It shows the quantities and percentages of flavonoids in $C$. leiocalycinus and $H$. griffithii

\begin{tabular}{|c|c|c|c|}
\hline Plant species & $\begin{array}{c}\text { Weight of } \\
\text { sample }\end{array}$ & $\begin{array}{c}\text { Weight of } \\
\text { flavonoids }\end{array}$ & \% age of flavonoids = weight of flavonoids x 100 \\
\hline C. leiocalycinus & $10 \mathrm{gm}$ & $0.28 \mathrm{gm}$ & $\%$ age of flavonoids $=2.8 \%$ \\
\hline H. griffithii & $10 \mathrm{gm}$ & $0.445 \mathrm{gm}$ & $\%$ age of flavonoids $=4.45 \%$ \\
\hline
\end{tabular}

Table 5. It shows the quantities and percentages of saponins in $C$. leiocalycinus and $H$. griffithii

\begin{tabular}{|c|c|c|c|}
\hline Plant species & $\begin{array}{c}\text { Weight } \\
\text { of sample }\end{array}$ & $\begin{array}{c}\text { Weight of } \\
\text { saponins }\end{array}$ & \% age of saponins = weight of saponins $\times 100$ \\
weight of sample
\end{tabular}


Table 6. It shows the quantities and percentages of phenolics in $C$. leiocalycinus and $H$. griffithii

\begin{tabular}{|c|c|c|c|}
\hline Plant species & $\begin{array}{c}\text { Weight of } \\
\text { sample }\end{array}$ & $\begin{array}{c}\text { Weight of } \\
\text { phenolics }\end{array}$ & \% age of phenolics = weight of phenolics $\mathbf{x ~ 1 0 0}$ \\
\hline weight of sample
\end{tabular}

\section{Conclusion}

This exploration discloses all the phytochemicals present in the plants like $C$. leiocalycinus and $H$. griffithii. This investigation also reveals the concentration of various phytochemicals present in the CME of both the plants by utilizing well established techniques.

C. leiocalycinus and $H$. griffithii are full of pharmacological and medicinal significance and are rich in phytochemicals that could be considered as responsible for their therapeutic effects, antimicrobial, antifungal and anti-oxidant activities. Furthermore, the plants screened for phytochemical constituents seemed to have the potential to act as a source of useful drugs and also to improve the health status of the consumers. Additional investigation is required for the isolation and assessment of the bioactivity like antibacterial and antifungal activities of different sections of the CME of $C$. leiocalycinus and $H$. griffithii.

\section{Authors' contributions}

Conceived and designed the experiments: M Ahmad, A Baqi \& RB Tareen, Performed the experiments: M Ahmad, Samiullah \& A Baqi, Analyzed the data: AU Rehman \& Samiullah, Contributed materials/ analysis/ tools: N Khan \& AU Rehman, Wrote the paper: M Ahmad, A Baqi \& A Manan.

\section{References}

1. Moosavi MA, Haghi A, Rahmati M, Taniguchi H, Mocan A, Echeverria J, Gupta VK, Tzvetkov NT \& Atanasov AG (2018). Phytochemicals as potent modulators of autophagy for cancer therapy. Can Lett 424 : 46-69.

2. Tuorkey MJ (2015). Cancer therapy with phytochemicals: present and future perspectives. Biomed and Environ Sci 28(11): 808-819.

3. Bacanli M, Aydin S, Basaran AA, \& Basaran N (2017). Are all phytochemicals useful in the preventing of DNA damage? Food and Chem Toxicol 109: 210-217.

4. Rahmani AH, Al Zohairy MA, Aly SM \& Khan MA (2014). Curcumin: a potential candidate in prevention of cancer via modulation of molecular pathways. Biome Res Inter 2014: 1-15.

5. Liu RH (2004). Potential synergy of phytochemicals in cancer prevention: mechanism of action. The $J$ of Nutri 134(12): 3479S-3485S.

6. Grabacka MM, Gawin M \& Pierzchalska M (2014). Phytochemical modulators of mitochondria: the search for chemopreventive agents and supportive therapeutics. Pharma 7(9): 913-942.

7. Aruoma OI, Spencer JPE, Rossi R, Aeschbach R, Khan A, Mahmood N, Munoz A, Murcia A, Butler J \& Halliwell B (1996). An evaluation of the antioxidant and antiviral action of extracts of rosemary and provencal herbs. Food and Chem Toxicol 34(5): 449-456.

8. Aqil F, Munagala R, Jeyabalan J \& Vadhanam MV (2013). Bioavailability of phytochemicals and its enhancement by drug delivery systems. Can Lett 334(1): 133-141.

9. Bode AM \& Dong Z (2014). Toxic phytochemicals and their potential risks for human cancer. Can Preven Res 8: 1-8.

10. Fransworth NR \& Wilson EO (1988). Biodiversity. National Academy Press, Washington DC, pp. 83-97.

11. Farnsworth NR (1966). Biological and phytochemical screening of plants. $J$ of Pharma Sci 55(3): 225-276.

12. Baqi A, Samiullah, Tareen RB, Mengal A, Khan N, Behlil F, Achakzai AKK, Anwer M, Rehman A \& Faheem M (2018). Determination of antioxidants in two medicinally important plants, Haloxylon 
griffithii and Convolvulus leiocalycinus, of Balochistan. Pure Appl Biol 7(1): 296-308.

13. Azizuddin A, Khan AM \& Mustafa S (2013). An update on secondary metabolites from Haloxylon species. $J$ of the Chem Soc of Pak 35(6): 1551-1572.

14. Santhi K \& Sengottuvel R (2016). Qualitative and quantitative phytochemical analysis of Moringa concanensis Nimmo. Int J Curr Microbiol Appl Sci 5(1): 633640.

15. Prabhavathi RM, Prasad MP \& Jayaramu M (2016). Studies on qualitative and quantitative phytochemical analysis of Cissus quadrangularis. Pelagia Res Libr Adv Appl Sci Res 7(4): 11-7.

16. Wadood A, Ghufran M, Jamal SB, Naeem M, Khan A \& Ghaffar R (2013). Phytochemical analysis of medicinal plants occurring in local area of Mardan. Biochem Anal Biochem 2(4): 1-4.

17. Khan AM, Qureshi RA, Ullah F, Gilani SA, Nosheen A, Sahreen S \& Murad W (2011). Phytochemical analysis of selected medicinal plants of Margalla Hills and surroundings. $J$ of Med Plants Res 5(25) 6055-6060.

18. Yusuf AZ, Zakir A, Shemau Z, Abdullahi M \& Halima SA (2014). Phytochemical analysis of the methanol leaves extract of Paullinia pinnata linn. J of Pharmacog and Phytoth 6(2): 10-16.

19. Yadav RNS \& Agarwala M (2011). Phytochemical analysis of some medicinal plants. J of Phytol 3(12).

20. Joseph BS, Kumbhare PH \& Kale MC (2013). Preliminary phytochemical screening of selected medicinal plants. Int Res J Sci Eng 1: 55-62.

21. Krvavych AS, Konechna RT, Petrina RO, Kyrka MS, Zayarnuk NL, Gulko RM, Stadnytska NE \& Novikov VP (2014). Phytochemical research of plant extracts and use in vitro culture in order to preserve rare wild species Gladiolus imbricatus. Res $J$ of Pharma, Biolog and Chem Sci ISSN: 0975-8585, 243.

22. Sonam M, Singh RP \& Pooja S (2017). Phytochemical screening and TLC profiling of various extracts of Reinwardtia indica. Inter $J$ of Pharma and Phytochem Res 9(4): 523-527.

23. Harborne JB (1984). Methods of plants analysis: In phytochemical methods, 2nd Eds. UK: Chapman and hall.

24. Bohm BA \& Kocipai-Abyazan R (1994). Flavonoid and condensed tannins from leaves of Vaccinum raticulation and Vaccinum calcyimium. Pacific Sci 48: 458463.

25. Ajuru MG, Williams LF \& Ajuru G (2017). Qualitative and quantitative phytochemical screening of some plants used in ethnomedicine in the Niger delta region of Nigeria. J of Food and Nutri Sci 5(5): 198205.

26. Hagerman AE, Riedl KM, Jones GA, Sovik KN, Ritchard NT, Hartzfeld PW \& Riechel TL (1998). High molecular weight plant polyphenolics (tannins) as biological antioxidants. $J$ of Agri and Food Chem 46(5): 1887-1892.

27. Kokate PD, Pai DS \& Thapliyal V (2004). Decadal variation in the heat and cold waves over India during 1971-2000. Mausam 55(2): 281-292.

28. Verma S, Mohanta $\mathrm{T}$, Revathy $\mathrm{T}$, Suthindhiran K \& Jayasri MA (2013). Phytochemical and pharmacological evaluation of selected plants. American J of Biochem and Biotec 9(3): 291-299.

29. Murugan M \& Mohan VR (2014). Phytochemical, FT-IR and antibacterial activity of whole plant extract of Aerva lanata (L.) Juss. Ex. Schult. J of Med Plants Stud 4(3): 51-57. 